University of South Florida

DIGITAL COMMONS

Digital Commons @ University of

@ UNIVERSITY OF SOUTH FLORIDA

South Florida

School of Geosciences Faculty and Staff

Publications

School of Geosciences

8-1992

\title{
Evidence of Regional Structural Controls on Vent Distribution: Springerville Volcanic Field, Arizona
}

\author{
Charles B. Connor \\ Florida International University, cbconnor@usf.edu \\ Christopher Condit \\ University of Massachusetts \\ Larry S. Crumpler \\ Brown University \\ Jayne C. Aubele \\ Brown University
}

Follow this and additional works at: https://digitalcommons.usf.edu/geo_facpub

Part of the Earth Sciences Commons

\section{Scholar Commons Citation}

Connor, Charles B.; Condit, Christopher; Crumpler, Larry S.; and Aubele, Jayne C., "Evidence of Regional Structural Controls on Vent Distribution: Springerville Volcanic Field, Arizona" (1992). School of Geosciences Faculty and Staff Publications. 1655.

https://digitalcommons.usf.edu/geo_facpub/1655

This Article is brought to you for free and open access by the School of Geosciences at Digital Commons @ University of South Florida. It has been accepted for inclusion in School of Geosciences Faculty and Staff Publications by an authorized administrator of Digital Commons @ University of South Florida. For more information, please contact digitalcommons@usf.edu. 


\title{
Evidence of Regional Structural Controls on Vent Distribution: Springerville Volcanic Field, Arizona
}

\author{
CHARLES B. CONNOR \\ Department of Geology, Florida International University, Miami \\ CHRISTOPHER D. CONDIT \\ Department of Geology and Geography, University of Massachusetts, Amherst \\ LARRY S. CRUMPLER AND JAYNE C. AUBEIE \\ Department of Geological Sciences, Brown University, Providence, Rhode Island
}

\begin{abstract}
Quantitative analysis of the geographic distribution of vents and comparison with regional structural, petrologic, and vent age data provide insight into the processes governing the emplacement of vents in the Springerville volcanic field, Arizona. A total of 409 vents in the Springerville volcanic field (SVF) have a mean distance to nearest neighbor vents of $955 \mathrm{~m}$, a much closer spacing than is common in some platform-type volcanic fields. Based upon a cluster analysis search radius parameter of $4500 \mathrm{~m}$, these vents comprise seven geographic clusters, with only five outlying vents occurring in the entire field. Cinder cone clusters in the westem portion of the field are significantly older than clusters in the eastern portion of the field ( $p$ value of $<0.001$ ), and there is a tendency for cluster age to decrease to the east. This is particularly evident when mean cluster ages are calculated for tholeiite, alkaline olivine basalt, and evolved alkaline rock types independently. Application of the two-point azimuth and Hough transform methods demonstrates that regional cinder cone alignments transect these clusters. The most prominent of these alignments trend ENE in the eastem portion of the field and WNW in the westem portion of the field, creating an overall arcuate pattem that is subparallel to the trend of the Mogollon Rim and the Colorado Plateau/Transition Zone boundary. These observations suggest that vents (and clusters) migrated from west to east in response to plate motion, but the general pattem of vent migration was complicated by regional structures, which enhanced the volume and duration of magmatism in some areas. The fractures or faults implied by vent alignments indicate that $S_{\text {hmin }}$ is oriented radial to the Colorado Plateau in the SVF. Preferred vent alignment orientations may be related to extension resulting from plateau uplift, and to a much smaller degree from a minor Basin and Range imprint. While regional in extent, the implied structures appear to differ significantly from some of those in several other plateau-marginal fields in that they cannot be related to major reactivated Precambrian structures. Our vent alignment data differ from those seen by other workers in the Zuni-Bandera and Mount Taylor fields, suggesting the stress field for the SVF is different from other fields in the proposed Jemez lineament. The stress field implied by vent alignment data, combined with structural data, suggests that the southwestem tectonic boundary of the Colorado Plateau of Brumbaugh (1987) should be extended southeastward to include the SVF at the plateau's southem boundary.
\end{abstract}

\subsection{Intent}

\section{INTRODUCTION}

The apparent correlation between regional structures and vent alignments in many cinder cone fields has suggested that vents are located at the top of vertical fractures along which magma ascends [Kear, 1964; Nakamura, 1977; Settle, 1979]. Vent alignments and parallel dikes [Delaney et al., 1986] have also been used by many workers [e.g., Zoback and Zoback, 1980, 1989; Zoback, 1989; Aldrich and Laughlin, 1984] as regional stress orientation indicators. One of the fundamental weaknesses implicit in using these kinds of data is that there has been a lack of rigor in defining vent alignments within volcanic fields, where vent density often makes alignment recognition difficult. In this paper we use several quantitative methods to search for vent clusters and alignments in the late Tertiary-Quaternary Springerville volcanic field (SVF), located on the southern margin of the Colorado Plateau. These methods include univariate statistics [Porter, 1972; Settle,

Copyright 1992 by the American Geophysical Union.

Paper number $92 \mathrm{JB} 00929$.

0148-0227/92/92JB-00929\$05.00
1979], cluster analysis [Connor, 1987, 1990], the Hough transform [Wadge and Cross, 1988], and the two-point azimuth method [Lutz, 1986; Wadge and Cross, 1988; Zhang and Lutz, 1989]. The results of our vent distribution analysis are compared with structural data collected in the field. This comparison is used to show the relationship between observed patterns in cinder cone distribution and regional crustal structure and to comment on the implied stress field surrounding the SVF. The analysis serves to clarify the relationship between SVF volcanism and the neotectonic structures which dominate the geology of the region. In addition, these data are examined for clues regarding the mechanisms governing the timing and location of cinder cone emplacement within the field.

\subsection{Background: Regional Setting}

Cinder cone volcanism has been widespread on the southern part of the Colorado Plateau physiographic province during the late Tertiary and throughout much of the Quaternary. With the exception of the Hopi Buttes, all of this volcanism has been concentrated within seven volcanic fields located near the margins of the plateau. The Springerville volcanic field is the southernmost of these fields (Figure 1); its southernmost flows 


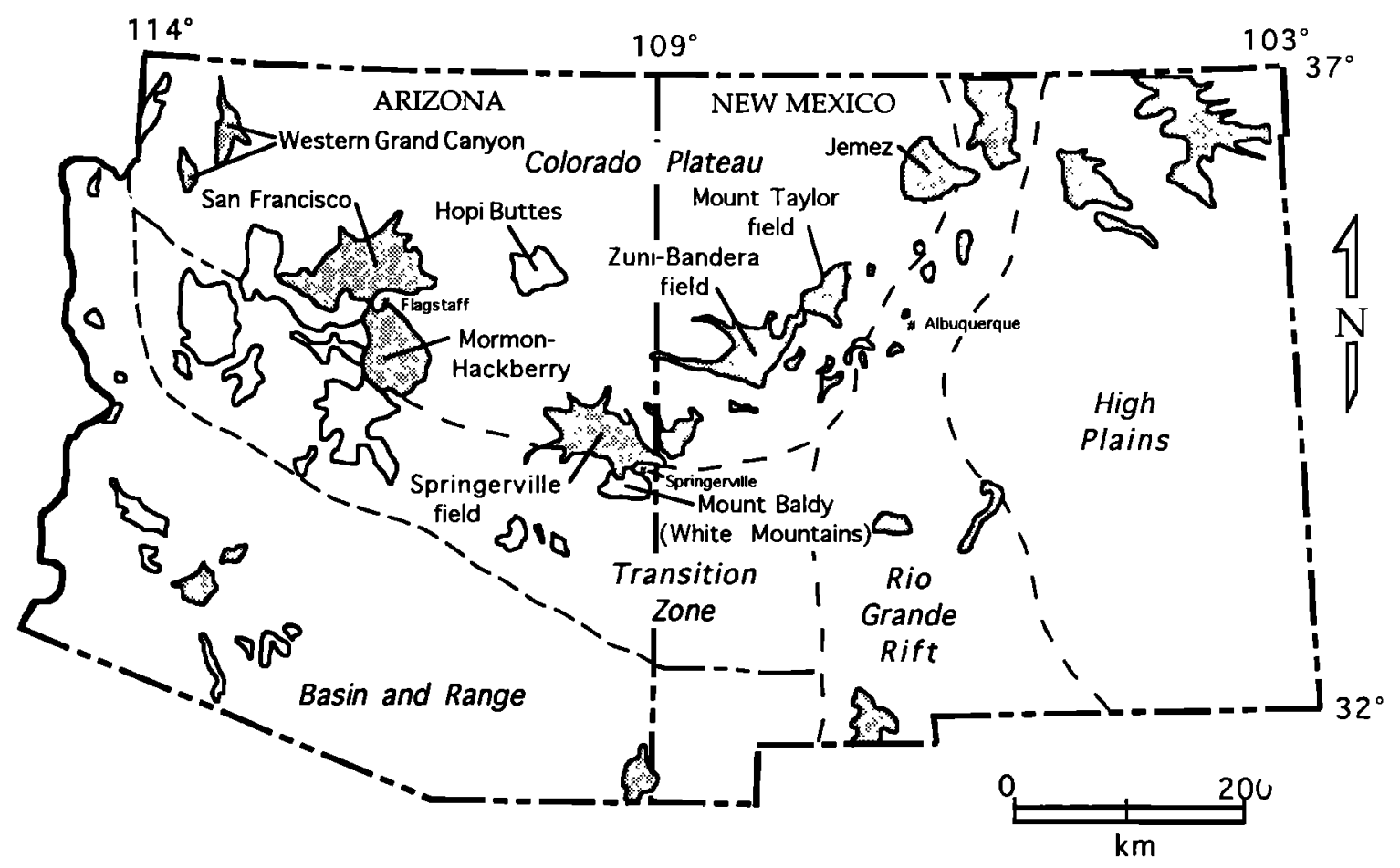

Fig. 1. The Springerville volcanic field is located along the southem margin of the Colorado Plateau, in central east Arizona. Physiographic provinces of the area delineated. The Mogollon Rim is a topographic escarpment which defines the boundary between the Transition Zone and the Colorado Plateau, south of the SVF. Shaded areas indicate volcanic fields less than $5 \mathrm{~m} . y$. old, oumlined areas indicate volcanic fields 5 to $16 \mathrm{~m}$.y. old [from Wolfe et al., 1983]. The Jemez lineament [Aldrich and Laughlin, 1984] is thought to be comprised of volcanic fields and associated structures extending from the Jemez volcanic field to the southwest, through the Mount Taylor, Zuni-Bandera, and Springerville fields.

straddle the Mogollon Rim, which forms the physiographic boundary between the Colorado Plateau and the Transition Zone. Geophysical models across the Transition Zone between the Colorado Plateau and Basin and Range (Figure 1) show a significant change in depth to the mantle from approximately $40 \mathrm{~km}$ in the interior of the plateau, to $22 \mathrm{~km}$ in the Basin and Range [Brumbaugh, 1987; Warren, 1969]. Near the SVF, this change starts near the northem boundary of the Transition Zone (the Mogollon Rim) about $25 \mathrm{~km}$ WSW of the SVF, where the seismic refraction study of Warren [1969] suggests a depth to the Moho of about $40 \mathrm{~km}$. South of this area the Transition Zone is further characterized by a change from flat lying relatively undisturbed Paleozoic rocks to a setting dominated by $B$ asin and Range faults and increased seismicity [Brumbaugh, 1987; Keller et al., 1979; Thompson and Zoback, 1979]. The SVF itself lies within an aseismic zone [Brumbaugh, 1987]. Although the physiographic boundary of the Colorado Plateau is well defined and abrupt, the tectonic boundary of the plateau on its southernmost margin is indistinct.

Aldrich and Laughlin [1984] have suggested the SVF lies at the southwestern end of the Jemez lineament. The Jemez lineament hypothesized by these workers is a broad $(\approx 50 \mathrm{~km}$ wide), $\mathrm{N} 52^{\circ} \mathrm{E}$ trending, tectonically active zone, characterized by volcanic fields and $\mathrm{N} 25^{\circ} \mathrm{E}$ striking en echelon faults, which, along with an inferred Precambrian province boundary, delineates the southeastern margin of the plateau (Figure 1). Clearly, interaction of the differing tectonic provinces of plateau and Basin and Range, and possibly the unique structural features of the Jemez lineament, may complicate the structural setting of the SVF. The relative importance of each has not been fully assessed. Therefore a primary goal of our investigation has been to evaluate the relationship between patterns in cinder cone distribution and tectonic features of the region.

\subsection{Background: Springerville Volcanic Field}

The SVF comprises 409 vents distributed over an area of approximately $3000 \mathrm{~km}^{2}$, located just north of the 9- to 7m.y.-old Mount Baldy (White Mountains) trachyte shield volcano (Figure 2; Nealey [1989]). The vent structures are dominantly cinder cones but include spatter cones, two shield volcanoes, four fissure vents, and five maar craters. Although there are some older lava flows [Condit et al., 1992; Cooper et al., 1990; Condit, 1984], the vents in this study were active between 2.1 and 0.3 m.y. ago and erupted approximately 300 $\mathrm{km}^{3}$ of basaltic lavas of dominantly alkalic affinities (alkaliolivine basalt $(\approx 47 \mathrm{vol} \%)$ and hawaiite $(\approx 28 \mathrm{vol} \%)$ [Condit et al., 1989]). Tholeiite ( $\approx 24 \mathrm{vol} \%$ ) and a limited number of more evolved alkalic rocks (mugearite and benmoreite, $<1$ vol \%) are also present but include only a few vents. In contrast to other volcanic fields along the margin of the Colorado Plateau, such as the San Francisco field [Wolfe et al., 1987a, b] and the Mount Taylor field [Crumpler, 1982], large silicic centers are not present in the SVF, and no high-silica flow units have been identified [Condit et al., 1989; Ulrich et al., 1989].

Detailed geological mapping [Condit et al., 1992] together with petrologic and stratigraphic investigations in the SVF have led to several additional observations that are relevant to the origin and history of volcanism in this area. First, the locus of active volcanism has shifted through time, and lava composition has evolved similarly in all locations accompanying this shift. Early lava flows in the SVF are sheet flows of tholeiitic composition and are widespread; the locations of the few unburied vents for these flows suggest no geographic preference in their distribution [Condit et al., 1989]. Following the effusion of tholeiite, alkali-olivine basalt became the dominant eruptive product. Early formed alkali-olivine basalt vents tend to be concentrated in the western portion of the field, and through time, eruptions 
migrated from west to east, coincident with the direction of motion of the North American Plate, a pattern similar to that suggested by Tanaka et al. [1986] for contemporaneous rocks of the San Francisco volcanic field. Condit et al. [1989] speculated that the SVF may be located over a thermal anomaly fixed with respect to the sublithospheric mantle. Evolved alkaline rocks (hawaiite, mugearite, and benmoreite), which are generally younger than other lavas, show a similar shift from west to east through time.

A second observation is that mapped regional faults do not transect the SVF. Unlike the San Francisco and Western Grand Canyon fields, no major basement-controlled regional faults or flexures have been identified in the sedimentary rocks surrounding the SVF. Some vents in the San Francisco [Tanaka et al., 1986; Ulrich and Nealey, 1976], Mormon [Ulrich et al., 1989; Holm et al., 1989], Zuni-Bandera [Kelley and Clinton, 1960; Aldrich and Laughlin, 1984], and Mount Taylor [Kelley and Clinton, 1960; Crumpler, 1980a,b, 1982] volcanic fields are associated with, or overlie, prominent dipslip faults. For example, four major volcanic centers within the San Francisco field line up along regional fault systems and many cinder cones are located over fractures and are elongate parallel to the fault system (e.g., vent 6735 [Ulrich and Bailey, 1987], vents 6604 and 6609 [Wolfe et al., 1987a], vents 2418 and 3132 [Newhall et al., 1987], and vent 80 [Moore and Wolfe, 1976]). Numerous vents in the ZuniBandera field show similar relationships to mapped fault zones [Aldrich and Laughlin, 1984; Kelley and Clinton, 1960]. In the Mormon volcanic field, vents align along north and northwest striking structures. Within the Mount Taylor field, which is located on the Acoma Sag, vents tend to form distinctive fissure patterns aligned parallel to or along NNE oriented structures or to be clustered in linear trends with orientations similar to basement structural trends [Crumpler, $1980 a, b, 1982]$.

\section{METHODS}

\subsection{Distribution of Cinder Cones}

The 409 vents used in this analysis (Figure 2) include 368 mapped vents and 41 vents delineated by their topographic expression from 7 1/2-min topographic maps and airphotos. These 41 vents are found in an unmapped $\approx 200-\mathrm{km}^{2}$ area in the south central part of the field. Within the mapped area, field relations suggest that 40 cinder cones are not associated with lava flows, being either barren cones or cones with buried flows. Some 266 vents are clearly associated with single lava flow units. Of the remaining 102 vents, 60 are associated with 30 flows ( 2 vents/flow), 21 with 7 flow units (3/unit), 8 with 2 flow units (4/unit), and one flow unit has 5 vents. Compositions are known for 240 vents; most analyses were obtained from associated flows near vent locations. A complete listing of vent coordinates is available from the authors on request.

The distance to nearest neighbor vent in the SVF is lognormally distributed with $>99 \%$ confidence. The geometric mean distance to nearest neighbor vent is $955 \mathrm{~m}$. Settle [1979] characterized cinder cone distribution in several cinder cone fields by reporting the nearest neighbor distribution in terms of quartiles. Using this approach, Settle found that platform-type fields, those consisting solely of independent monogenetic vents, have a greater vent spacing than volcanictype fields, which consist of vents parasitic to a larger polygenetic volcano. Comparing the SVF to two other platform-type fields, it is clear that the SVF has much more closely spaced vents than the other platform-type cinder cone fields cited (Table 1). As this is true at each quartile, the observation is true of the distribution as a whole and is not dependent on the presence or lack of outlying cinder cones or a few very closely spaced vents. The SVF has median and upper (75\%) quartile distances which are shorter than two of the three volcanic-type fields cited (Mauna Kea and Kilimanjaro). A map of the density distribution of cinder cones in the SVF (Figure 3) shows that vents are most densely concentrated in the south central portion of the field. Contours showing high vent concentrations (greater than 14 vents $/ 177 \mathrm{~km}^{2}$ ) are elongate in a WNW orientation (Figure 3 ).

\subsection{Cluster Analysis}

Univariate descriptive statistics cannot fully characterize vent distribution because they cannot describe spatial

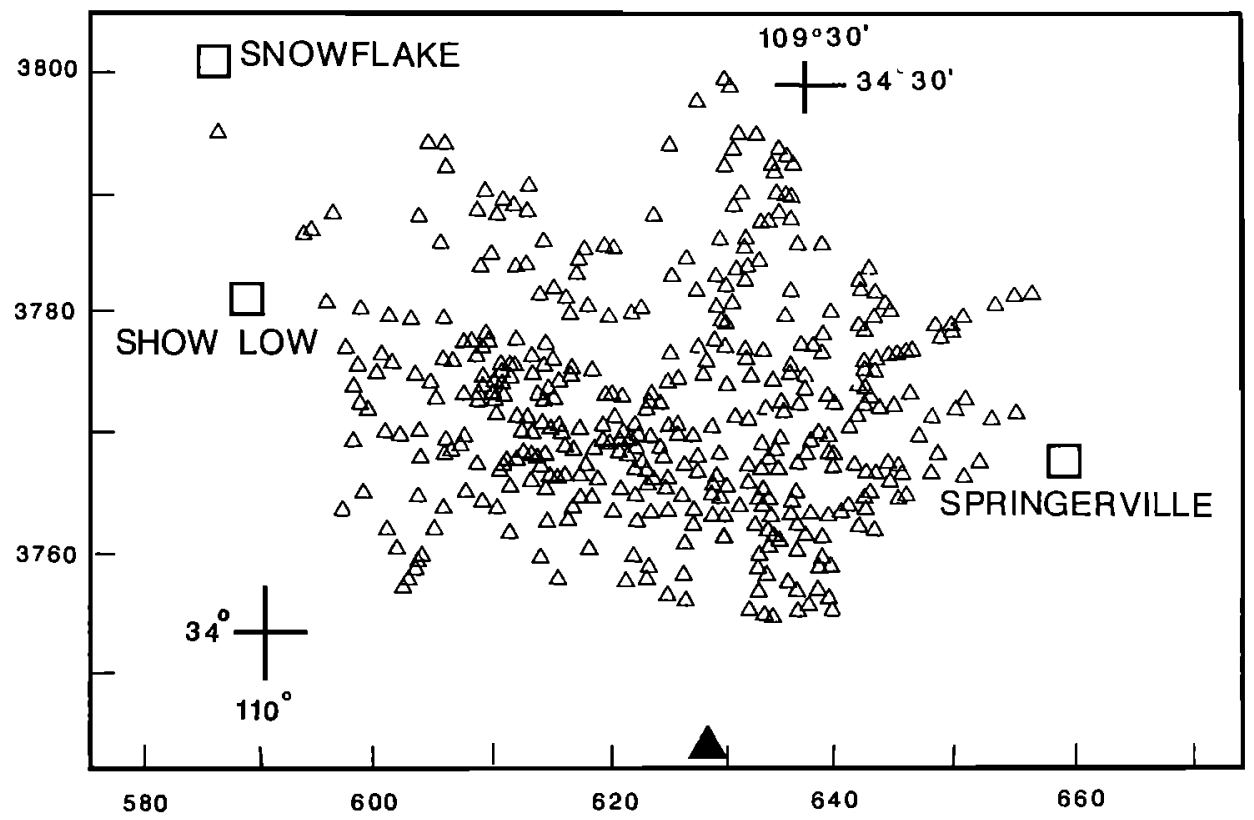

Fig. 2. Map of the location of all (409) vents in the Springerville volcanic field (triangles). Mount Baldy, a Tertiary trachytic shield volcano (large solid triangle), is located about $20 \mathrm{~km}$ south of the SVF. The towns of Springerville, Show Low, and Snowflake are shown as open boxes. Universal Transverse Mercator (UTM) coordinates are given at the margin of the map, labelled at $20-\mathrm{km}$ intervals (10-km tick spacing). 
TABLE 1. Near-Neighbor Distributions for Some Volcanic Fields

\begin{tabular}{|c|c|c|c|c|}
\hline \multicolumn{4}{|c|}{ Distance to Near-Neighbor Vent by Ouartile, $m$} & \multirow{2}{*}{$\begin{array}{l}\text { Number } \\
\text { of cones }\end{array}$} \\
\hline & $25 \%$ & $50 \%$ & $75 \%$ & \\
\hline \multicolumn{5}{|c|}{ Platform-Type Fields } \\
\hline Springerville field & 710 & 979 & 1407 & 409 \\
\hline Nunivak Island & 1047 & 1547 & 2955 & 83 \\
\hline \multicolumn{5}{|c|}{ Volcanic-Type Fields } \\
\hline Mauna Kea & 569 & 813 & 1524 & 168 \\
\hline Mount Etna & 425 & 780 & 1373 & 87 \\
\hline Mount Kilimanjaro & 679 & 1152 & 1879 & 205 \\
\hline
\end{tabular}

Distribution of distances (in meters) to nearest-neighbor vent by quartile for various platform-type and volcanic-type cinder cone fields [Settle, 1979; Connor, 1987; this study]. SVF vents are more closely spaced than vents in the Nunivak Island and Michoacán platform-type fields and, at some quartiles, than vents in the Mauna Kea and Mount Kilimanjaro volcanic-type fields.

variation in distribution. The goal of cluster analysis is to identify natural vent clusters within the SVF. This is important because quantitative alignment methods are adversely affected by inhomogeneities in vent distribution. By identifying clusters prior to making the alignment analysis, these effects are minimized. Furthermore, the occurrence and distribution of clusters themselves may provide insight into the processes governing vent emplacement.

Cluster analysis is a computer-based exploratory data analysis technique that searches for clusters, or modes, in vent distribution while making a minimum of assumptions. Assumptions about the significance of a given vent spacing inherent in most other methods need not be made in cluster analysis. For example, it is necessary to specify a grid spacing and an area about each vent, or grid point, within which the number of vents will be summed in order to produce a vent density contour map such as the one in Figure 3 [Porter, 1972; Baker, 1974; Connor, 1987]. The appearance of the density contour map will change if these search parameters are changed. The validity of using one size search area or grid spacing over another is difficult to assess. Cluster analysis avoids the interpolation associated with contouring altogether and provides a systematic approach to dealing with search areas. Here, a uniform kemel density fusion cluster analysis is used [Wong, 1982; Wong and Lane, 1983; Wong and Schaak, 1982; Sarle, 1985]. The application of this technique to cinder cone distribution problems was described by Connor [1987, 1990].

Briefly, this cluster analysis provides a means of recognizing modes in vent distribution in a quantitative way. The method is considered robust because even if two clusters overlap slightly, they will still be recognized as two distinct clusters. A circle of radius $r$ is drawn about each vent within the field. The number of cones to fall within this circle is $f\left(X_{i}\right)$, for the $i$ th vent. Ultimately, an $n \times n$ matrix is calculated for the $n$ number of vents in the field. For each element in the matrix,

$$
\begin{aligned}
& d^{*}\left(X_{i}, X_{j}\right)=\frac{1}{2}\left[\frac{1}{f\left(X_{i}\right)}+\frac{1}{f\left(X_{j}\right)}\right], \quad d\left(X_{i}, X_{j}\right)<r \\
& d^{*}\left(X_{i}, X_{j}\right)=\infty, \text { otherwise }
\end{aligned}
$$

where $d\left(X_{i}, X_{j}\right)$ is the map distance between the $i$ th and $j$ th vent. Once this matrix is calculated, individual vents are linked using this matrix and a single linkage clustering algorithm [Hartigan, 1975; Le Maitre, 1982]. If the density fusion, $d^{*}$, between two clusters is less than the maximum $d^{*}$ between any two vents within either cluster, then the two clusters are not linked. This step makes the recognition of overlapping clusters possible by reducing the importance of individual vents. However, it can also lead to the assignment of some vents to an inappropriate cluster if the densities of vents in one cluster is low in comparison with another, nearby cluster [Sarle, 1985]. This characteristic does not have an

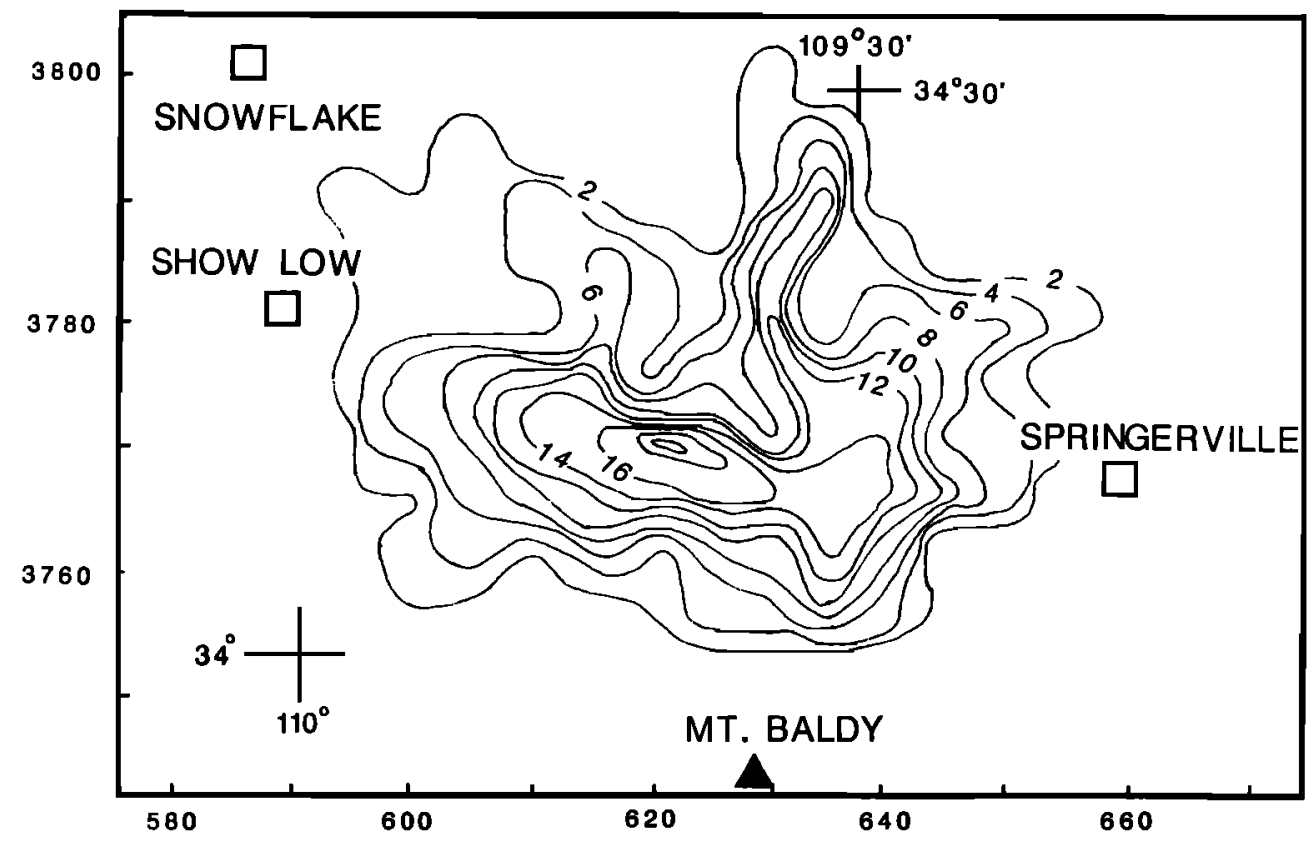

Fig. 3. Vent density distribution contour map based on a contouring grid spacing of $10 \mathrm{~km}$ and search radius of $7.5 \mathrm{~km}$ about each grid point. The grid point values were contoured using a minimum curvature contouring algorithm. Contour interval is 2 vents $/ 172 \mathrm{~km}^{2}$. Note that the highest concentration of cinder cones in the SVF is found in the south central portion of the field. In this area, contour lines are elongate in a WNW orientation. UTM coordinates are given at the margin, as in Figure 2. 
adverse effect on the results unless vent density is low and clusters are poorly developed. The single linkage clustering process continues repetitively until a stable number of clusters is found. A map is then made, showing the distribution of individual vents by cluster membership. Of course, changing the search radius, $r$, will change the number of clusters on this map. Therefore the analysis is repeated using many search radii. If clustering is a significant feature of vent distribution, then the number of clusters, and more particularly the distribution of clusters, will not change or will change only slightly with changing search radius.

For SVF vents, the change in the number of vent clusters with changing search radius is illustrated in Figure 4 . At search radii greater than $6000 \mathrm{~m}$, a single cluster exists with four outliers. Between 6000 and $5500 \mathrm{~m}$, several large clusters form, and at search radii less than approximately $4200 \mathrm{~m}$, these large clusters begin to pull apart in an apparently random manner, and the number of clusters with decreasing search radius begins to increase much more rapidly (Figure 4).

A total of 12 maps was produced, illustrating the distribution of vents by cluster membership at different search radii. Seven clusters persist over a range of search radii (see Figure 5 caption) with only slight changes in membership. The distribution of these clusters is illustrated in Figure 5, using a search radius of $4500 \mathrm{~m}$. These clusters have between 27 and 101 cinder cones each. In addition to these seven clusters, five cones are classified as outliers because they either do not cluster with other cinder cones at all at this search radius or they form a cluster of only three cones (Figure 5). A total of four vents appear to be misassigned at a search radius of $4500 \mathrm{~m}$ as a result of low vent densities in some areas, such as between clusters 1 and 2 (Figure 5).

\subsection{Two-Point Azimuth Analysis}

The two-point azimuth method, developed by Lutz [1986] and first applied to volcano distribution problems by Wadge and Cross [1988], provides a statistical means of identifying preferred orientations and/or anisotropy in vent distribution. Within a given area, some vents will align even if these vents are distributed according to a uniform random process. For example, vents emplaced in an isotropic stress field may form an alignment by chance. Such an alignment could be misinterpreted as an indication of a preferred horizontal stress orientation. The two-point azimuth method helps distinguish between alignments formed by random chance and those

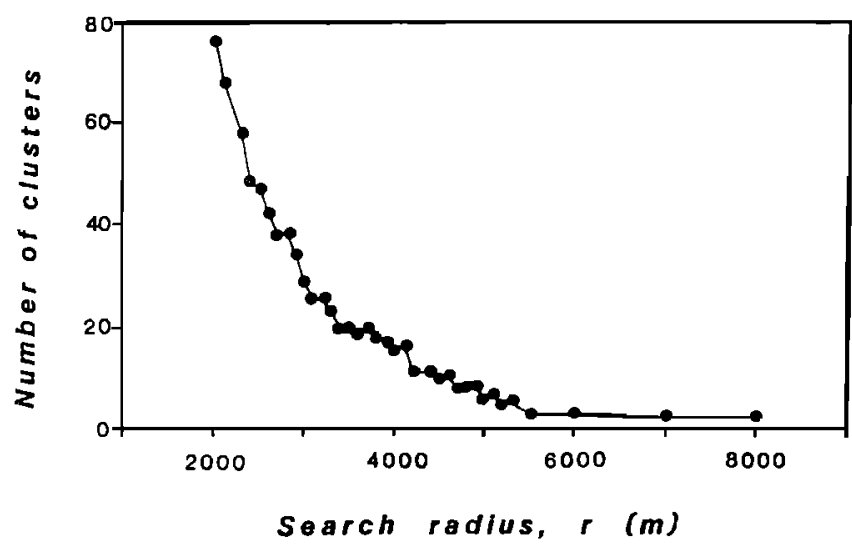

Fig. 4. Change in the number of clusters with changing search radius about each vent. The clustering method used is a modification of Wong's [1982] density fusion method [Sarle, 1985]. Solid circles are plotted to indicate the number of clusters found by the analysis at a specific search radius. Note the rapid increase in the number of clusters at search radii less than approximately $4200 \mathrm{~m}$. produced by some underlying geological mechanism, such as anisotropy in the stress field.

The basis of the two-point method is a Monte Carlo simulation. Any two vents in the volcanic field lie along a line. As a first step in the analysis, lines are drawn from each vent through all other vents in the field. The azimuth of each of these lines is measured, resulting in a total of $n(n-1) / 2$ azimuths, where $n$ is the number of vents. The number of twopoint alignments of a given orientation will depend on both the presence of vent alignments and the shape of the boundary of the volcanic field, since vent pairs tend to align in a preferred orientation if the entire field is elongate. The Monte Carlo simulation is made to correct for the effect of field shape. In this case, we followed Lutz's [1986] example and chose the vents at the margin of each cluster as the vertices of a polygonal area for the Monte Carlo simulation. For each simulation, $n$ points were randomly plotted within this area, each point representing the location of a vent. The azimuth from each point to every other point within the polygon was found, and the cumulative frequencies were compared with the observed vent azimuth frequency distribution at $10^{\circ}$ intervals. If actual vents tend to align preferentially in a given orientation, this will emerge through comparison with the Monte Carlo results, using a t test [Lutz, 1986].

The two-point azimuth method was applied on a cluster by cluster basis to the seven largest clusters in the field (Figure 5). The outcome of the analysis indicates that significant anisotropy exists in the distribution of cinder cones within each cluster. Significant azimuthal orientations are found within each cluster at the $95 \%$ confidence level (Table 2). The azimuthal directions identified as statistically significant are not identical in all clusters, but they appear to vary in a consistent manner. Significant azimuthal directions are WNW oriented in clusters 2 and 3 (Figure 5), coinciding with the elongate area of highest vent density (Figure 3 ). Significant azimuthal directions are ENE oriented in clusters 5 and 6 in the eastern part of the field and in clusters 1 and 3 in the western and central part of the field. Clusters 4 and 7 , in the central part of the field, have significant N-S azimuthal directions, and significant NE orientations are identified in cluster 4 .

\subsection{The Hough Transform}

The two-point azimuth method does not provide information on the actual location of alignments; it simply indicates the orientation of significant anisotropy. Wadge and Cross [1988] applied a computer enhancement technique, the Hough transform, to cinder cone distributions in Michoacán, Mexico, to determine the actual locations of alignments. We apply it in conjunction with the two-point azimuth method to identify alignments in the SVF, again on a cluster by cluster basis.

Each vent in a cluster lies along an infinite number of lines, each line having a unique azimuth. These lines can be represented in polar coordinates as curves. A point on one of these curves has the coordinates $\rho$ and $\theta$, where $\rho$ is the shortest (normal) distance from that arbitrary point to the line, and $\theta$ is the angle of that normal from zero [Wadge and Cross, 1988]. In this case, we chose the mean cluster centroid as the center of the coordinate system. If, for example, four vents within a cluster align exactly, the four sinusoidal curves associated with these vents in $\rho, \theta$ parameter space will intersect at a single $\rho, \theta$ coordinate, which in turn yields the orientation and position of the line, relative to the cluster centroid.

In practice, discrete $\Delta \theta$ and $\Delta \rho$ are used. Here, we use $\Delta \theta=$ $2^{\circ}$ and $\Delta \rho=400 \mathrm{~m}$, the same values used by Wadge and Cross [1988] and Connor [1990], taken to represent reasonable 


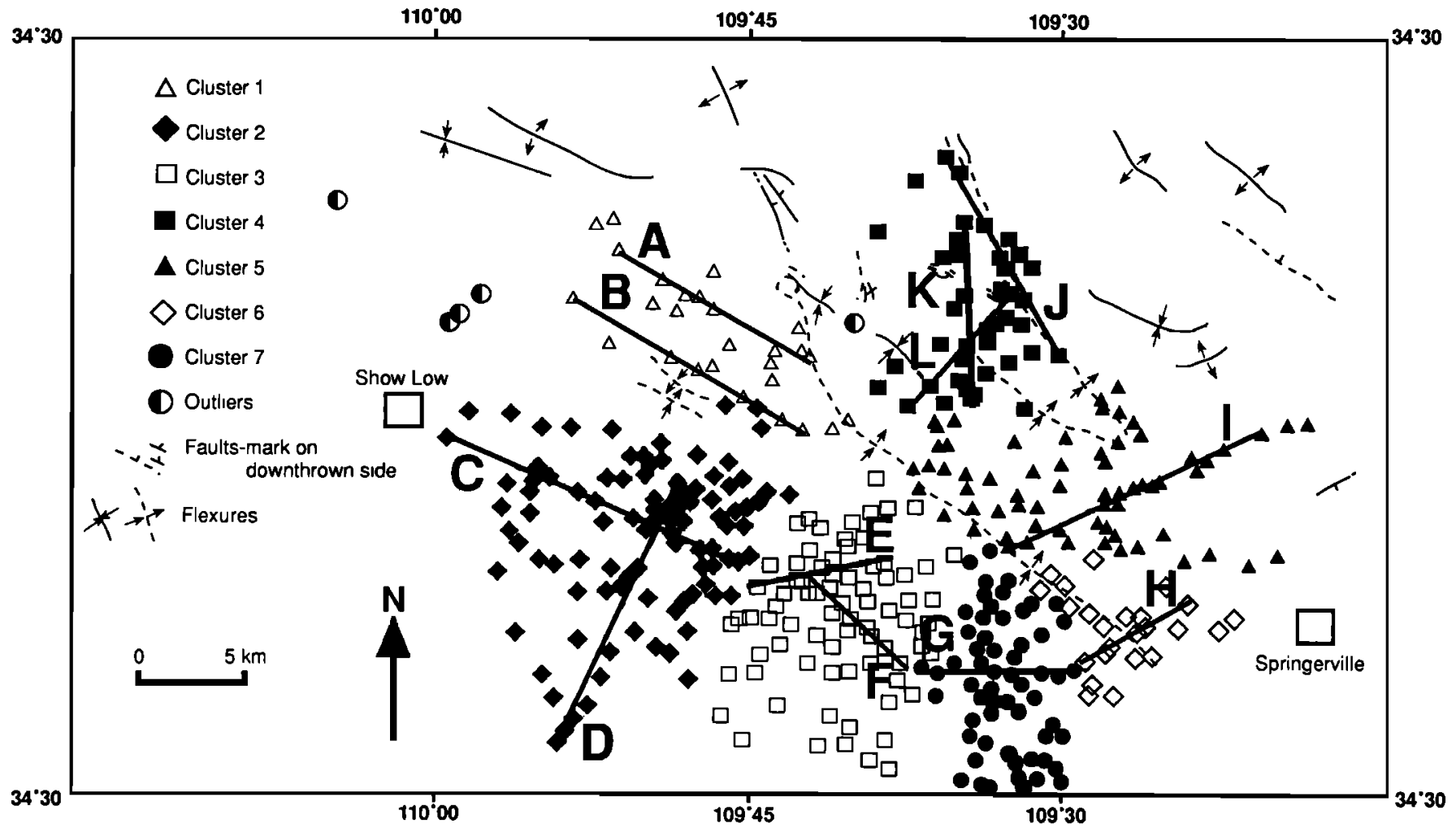

Fig. 5. Vents plotted by cluster membership. Vents belonging to the same cluster are plotted using the same symbol, centered on the vent location. This map illustrates the results of a cluster analysis using a search radius of $4500 \mathrm{~m}$, which is well representative of the large clusters in the field. Other search radii produce different cluster configurations. The clusters shown are stable over the following search radii, plus or minus a few vents: cluster 1, 4200 to $5500 \mathrm{~m}$; cluster 2, 4200 to $5500 \mathrm{~m}$; cluster 3,4200 to $5500 \mathrm{~m}$; cluster 4,2900 to $4500 \mathrm{~m}$; cluster 5,3700 to $5000 \mathrm{~m}$; cluster 6,3500 to $4500 \mathrm{~m}$; cluster 7,2700 to $4500 \mathrm{~m}$. Vent alignments identified using the Hough transform are indicated by solid lines and are labelled A-L. These alignments were identified on a cluster by cluster basis; nonetheless, they often meet or can be extrapolated across cluster boundaries, forming arcuate trends in the southem part of the field.

fracture zone sizes. Experimentation showed that the number and orientation of alignments did not vary significantly by changing these parameters. The Hough transform is sensitive to the number of cinder cones used in the analysis and the shape of the cinder cone cluster. The more cinder cones in a cluster, the more likely it is that several cinder cones will align. If a cluster is elongate, alignments will likely be found in the direction of elongation. Consequently, we were careful to compare the results of the Hough transform with the results of the two-point azimuth method, which takes cluster shape into account.

Within each cluster, one or two alignments that consist of numerous vents were identified using the Hough transform. Most of these alignments have orientations similar to those recognized as significant using the two-point azimuth method at the $95 \%$ confidence level. These alignments consist of six and usually seven or more vents, usually in proportion to the number of cinder cones in the entire cluster (Figure 5; Table 2).

These alignments were identified within each cluster independently. Nonetheless, the alignments often meet, nearly meet, or can be extrapolated across cluster boundaries. This is particularly true for alignments in the central and southern portion of the field. Vent alignments $\mathrm{C}, \mathrm{E}$, and I create a nearly continuous alignment with an arcuate shape which spans the southern half of the field and which is approximately $65 \mathrm{~km}$ in length. This alignment divides in the central portion of the field, within cluster 3, east of which a second arcuate alignment forms (alignments $F, G$, and $H$ of Figure 5).
In five cases, the Hough transform identifies alignments which consist of six or more aligned vents and do not correspond to significant orientations found using the twopoint azimuth method (Table 2; Figure 5). Two of these are found in the NW part of the field within an elongate cluster (cluster 1). The two-point azimuth method minimizes the effect of cluster shape, and as a result any trend in this orientation is difficult to identify with the two-point method. Another such alignment is located in cluster 2 and has an azimuth of $020^{\circ}$. This alignment consists of nine cones and transects the entire cluster.

\section{StRuctural Features aNd Vent Distribution PATTERNS}

Lavas of the SVF cap a thick sequence of sedimentary rocks of Permian to Cretaceous age that dip to the NNE at $\approx 0.5^{\circ}$ [Condit et al., 1989] and form the Mogollon Slope, southernmost tectonic division of the Colorado Plateau [Kelley and Clinton, 1960]. This sedimentary sequence is nearly flat lying and is essentially undeformed. The entire Mogollon Slope area around the SVF lacks the north striking normal faults characteristic of the western margin of the plateau [Wernicke and Axen, 1988], the northeast trending structures characteristic of the southwestern plateau [Shoemaker et al., 1978; Tanaka et al., 1986; Holm and Cloud, 1990], or the pronounced north and northwest striking faults of the Mormon volcanic field [Holm et al., 1989]. In the sedimentary exposures to the north of the SVF, with the 
TABLE 2. Summary of the Alignment Analysis

\begin{tabular}{|c|c|c|c|c|c|c|}
\hline \multirow{2}{*}{\multicolumn{2}{|c|}{$\begin{array}{l}\text { Cluster and } \\
\text { No. of Vents }\end{array}$}} & \multirow{2}{*}{$\begin{array}{c}\begin{array}{c}\text { Two-Point } \\
\text { Azimuth Direction }\end{array} \\
070-080\end{array}$} & \multicolumn{4}{|c|}{ Hough Transfom } \\
\hline & & & $\begin{array}{r}\text { Azimuth } \\
-\end{array}$ & $\begin{array}{c}\text { No. Vents } \\
-\end{array}$ & Length & $\begin{array}{r}\text { Vents/km } \\
-\end{array}$ \\
\hline 1 & 27 & $\begin{array}{r}070-080 \\
- \\
-\end{array}$ & $\begin{array}{l}295(\mathrm{~A}) \\
298(\mathrm{~B})\end{array}$ & $\begin{array}{l}- \\
6 \\
6\end{array}$ & $\begin{array}{l}16.3 \\
19.0\end{array}$ & $\begin{array}{l}0.37 \\
0.32\end{array}$ \\
\hline 2 & 101 & $\begin{array}{r}280-290 \\
-\end{array}$ & $\begin{array}{l}291 \text { (C) } \\
022 \text { (D) }\end{array}$ & $\begin{array}{l}9 \\
9\end{array}$ & $\begin{array}{l}19.8 \\
21.2\end{array}$ & $\begin{array}{l}0.45 \\
0.42\end{array}$ \\
\hline 3 & 84 & $\begin{array}{r}070-080 \\
* 300-310\end{array}$ & $\begin{array}{l}071(\mathrm{E}) \\
307(\mathrm{~F})\end{array}$ & $\begin{array}{l}9 \\
9\end{array}$ & $\begin{array}{l}10.0 \\
10.4\end{array}$ & $\begin{array}{l}0.90 \\
0.87\end{array}$ \\
\hline 4 & 38 & $\begin{array}{r}020-030 \\
040-050 \\
350-360 \\
-\end{array}$ & $\begin{array}{l}042(\mathrm{~L}) \\
356(\mathrm{~K}) \\
331(\mathrm{~J})\end{array}$ & $\begin{array}{l}- \\
6 \\
6 \\
6\end{array}$ & $\begin{array}{l}11.4 \\
12.2 \\
17.0\end{array}$ & $\begin{array}{l}0.53 \\
0.49 \\
0.35\end{array}$ \\
\hline 5 & 66 & $060-080$ & 061 (I) & 9 & 20.7 & 0.43 \\
\hline 6 & 29 & $\begin{array}{l}050-060 \\
070-080\end{array}$ & $055(\mathrm{H})$ & $\begin{array}{l}7 \\
-\end{array}$ & 9.2 & $\begin{array}{r}0.76 \\
-\end{array}$ \\
\hline 7 & 56 & $\begin{array}{r}000-010 \\
-\end{array}$ & $090(G)$ & 8 & $11 . \overline{3}^{-}$ & 0.71 \\
\hline
\end{tabular}

Clusters are numbered as in Figure 5. The results of the two-point azimuth analysis are reported for each cluster. All orientations, calculated at $10^{\circ}$ intervals, found to be significant at the $95 \%$ confidence level are given (except the asterisk, for which the confidence interval is $90 \%$ ). Specific alignments are identified using the Hough transform; these are identified by letter as in Figure 5. The azimuth, number of vents, alignment length measured from first to last vent in the alignment, and number of vents/kilometer are given for each alignment. There is general agreement between the results of the Hough transform and the two-point azimuth method. In cases in which the two-point azimuth orientation does not correspond to the azimuth of an alignment identified using the Hough transform, or vise versa, a dash is entered in the corresponding column(s).

*Confidence level of $90 \%$ for this interval.

exception of three normal faults of minor displacement and less than $15-\mathrm{km}$ lengths, the few structural elements include gentle anticlines and synclines [Wilson et al., 1960, 1969; Kelley and Clinton, 1960], most with WNW to NW trends, some of which extend for distances over $20 \mathrm{~km}$. Several of these trends continue into the field, expressed as local normal faults that grade into flexures [Crumpler et al., 1989; Condit et al., 1992]. That these flexures postdate flows has been amply demonstrated [Aubele et al., 1986].

These flexures form topographic escarpments and are the most prevalent structural features of the field. Starting from the south center of the field (center of cluster 3, Figure 5), there is a decrease in elevation to the northeast, with a total drop of approximately $1 \mathrm{~km}$. This drop occurs as a series of three discrete topographic steps, expressed as arcuate northeast facing escarpments (Figure 5). From southwest to northeast, the topographic relief decreases from approximately $250 \mathrm{~m}$ across the first step to $100 \mathrm{~m}$ across the second, and to $80 \mathrm{~m}$ across the northeast step. All of these steps have variable strikes reflecting their arcuate traces: WNW in the northwestern and central portions of the field changing to NNW in the northeastern portion of the field. The topographically lowest area in the region occurs immediately NE of the field. Approximately half to three fourths of this drop in elevation can be accounted for by the $0.5^{\circ} \mathrm{NNE}$ regional dip and by the accumulation of flows which stack up to the southwest toward the center of the field; the rest appears to result from downwarping to the northeast. The northeastmost of these flexures corresponds to a vent alignment (alignment J, Figure 5).

The overall structural fabric within the field is further defined by two other passive folds (between alignments $B$ and $C$,
Figure 5) and locally faulted and tilted basaltic flow units, most found in the north and northeastern part of the field. In the westem and central part of the field, many of these features are aligned WNW to NW, parallel and subparallel to vent alignments (Figure 5). Structural features of other orientations are present as well, indicating the local complexities of the stress field acting on the area concomitant to and following the emplacement of cinder cones. In order of prominence, these structures trend NW, ENE, NE, and north [Crumpler et al., 1989].

Four widely separated eruptions appear to have been controlled by fissures, as suggested by their elongate pyroclastic deposits [Condit et al., 1992]; in addition, a single dike is found within the field. These features tend to confirm the interpretation that cinder cone alignments are related to structural trends. Two of these fissure-controlled vent structures are located on and elongated parallel to vent alignments. Elongate vents form the central part of alignment I (Figure 5). To the north of this alignment, two cinder cones are connected by a fissure ridge of spatter and form the northern end of alignment $K$ (Figure 5). Located roughly between these alignments, two vents erupted along a $200-\mathrm{m}$ long fissure oriented $080^{\circ}$. In addition to these fissure vents, a single dike about $1.1 \mathrm{~km}$ long has been mapped. Located in the south central part of the field, the dike trends $058^{\circ}$, subparallel to cinder cone alignments $E, H$, and $I$.

\section{Discussion}

Reasons for the emplacement of platform-type cinder cone fields instead of single, polygenetic centers are not entirely clear but may relate to the relative rates of magma production. 
Cinder cone fields may form in areas having relatively low magma supply rates [Fedotov, 1981; Hasenaka and Carmichael, 1985]. Given a low magma supply rate, conduits are not maintained in the crust and individual magma batches ascend varied pathways to the surface, rather than ascending in the same conduit repeatedly [Fedotov, 1981]. The SVF certainly does have a low magma supply rate compared with many individual volcanic centers. The SVF produced lavas at an average rate of $1.5 \times 10^{-4} \mathrm{~km}^{3} / \mathrm{yr}$ between 2.0 and $0.3 \mathrm{~m} . \mathrm{y}$. ago [Condit et al., 1989]; peak lava production rates between 2.0 and $1.0 \mathrm{~m}$.y reached $2.8 \times 10^{-4} \mathrm{~km}^{3} / \mathrm{yr}$. This is 1 to 2 orders of magnitude less than the output rate of most basaltic centers listed by Crisp [1984]. The Mount Baldy stratovolcano just to the south of the SVF, with an estimated volume of $280 \mathrm{~km}^{3}$ [Merrill and Pewe, 1976], appears to have formed in about 0.5 m.y. [Nealey, 1989], with a production rate of $5.6 \times 10^{-4} \mathrm{~km}^{3} / \mathrm{yr}$, about twice that of the peak production of the SVF. The output rate of basaltic lavas in the San Francisco Peak volcanic field has been similar to that of the SVF, with a maximum long-term eruption rate (between 0.73 and $0.1 \mathrm{~m} . \mathrm{y}$.) of about $3.0 \times 10^{-4} \mathrm{~km}^{3} / \mathrm{yr}$; silicic peak output for this field was about $2.0 \times 10^{-4} \mathrm{~km}^{3} / \mathrm{yr}$ between 1.0 and $0.25 \mathrm{~m} . \mathrm{y}$. if adjusted to reflect only extrusive rocks (without correcting for porosity) [Tanaka et al., 1986]. Similar rates are suggested for the Mount Taylor volcanic field by Crumpler [1990] at between 1.1 and $1.6 \times 10^{-4} \mathrm{~km}^{3} / \mathrm{yr}$ between 3.5 and 1.5 m.y., although Perry et al. [1990] give peak production rates as low as $4.0 \times 10^{-5} \mathrm{~km}^{3} / \mathrm{yr}$ for a central cone of the same field. Low magma supply rate and cinder cone volcanism are coincident in the SVF and perhaps in many of the plateau-margin cinder cone fields. This may indicate a causal relationship.

Univariate descriptive statistics and cluster analysis have demonstrated that vents are closely spaced in the SVF compared with some other active volcanic fields and occur in clusters, rather than having regular or uniform random distribution. In a field of 409 vents, only five outlying vents occur. These observations suggest that through time there is a tendency for successive melting events to occur near one another, rather than randomly over the entire area of the field. This result is consistent with the idea that cinder cone clusters owe their origin primarily to low rates of magma generation in localized areas, rather than to the dispersal of magmas by crustal structures.

Using K/Ar, paleomagnetic, and stratigraphic data gathered by Condit et al. [1989], we have compared the ages of rocks of differing petrologies between clusters. Condit et al. [1989] classified rocks in the SVF as alkali olivine basalts (AOB), evolved alkaline rocks (EAR, including hawaiite, mugearite, and benmoreite), and tholeiite. Applying their classification, we find a systematic change in the ages of the three rock types from cluster to cluster. Within individual clusters, the average age of AOB rocks is greater than the average age of EAR rocks (Table 3), perhaps a result of longer residence time needed for magmatic differentiation. Between clusters, however, this relationship does not hold true. For instance, the average age of EAR rocks in cluster 1 is significantly greater than that of AOB rocks in cluster 3 . Comparison of similar rock types between clusters suggests a systematic variation in the timing of eruption of magmas of differing compositions. Clusters 1 and 2, located in the western portion of the field (Figure 5), contain significantly older rocks of a given type than clusters located further to the east ( $p$ value of $<0.001$ ). This is true for tholeiite, AOB, and EAR rocks. In general, there is a decrease in the ages of rocks from west to east, among all petrologic types, consistent with the fixed-source model proposed by Condit et al. [1989], in which eruptive activity migrated from west to east in response to the westward motion of the North American Plate relative to a fixed source [Condit et al., 1989]. Volcanism in the SVF reflects this motion by shifting from one cluster to another through time, rather than by the continuous migration of vent loci through time. This is analogous in some respects to Hawaiian hot spot volcanism [Jackson et al., 1972], where individual shields are built through time in response to the continuous motion of the Pacific plate with respect to a fixed source. Also analogous to Hawaiian volcanism, activity does not cease in one cluster simply because it has begun in another.

The picture in the SVF appears to be more complex than in its Hawaiian counterpart in several respects, not surprising given the differing lithospheric regimes. Comparatively young EAR rocks are found in cluster 3 , in the south central portion of the field (Figure 5) where cinder cone densities are greatest (Figure 3). Although the EAR rocks in cluster 3 are on average younger than those found further east, the variance in the ages of rocks in this cluster is larger than that of other clusters (Table 3). In fact, some of the oldest EAR rocks found in the field occur within this cluster. Similarly, cluster 2 , which contains on average comparatively old AOB and EAR rocks, also contains some of the youngest. Apparently the eruption of magmas is influenced by additional factors, some discussed below, complicating the general west to east pattern of vent migration.

Several authors have suggested that a coincidence between areas of magma generation and faulting or fracturing of the crust is necessary for the emplacement of platform-type

TABLE 3. Mean Ages of Rock Types in Different Clusters

\begin{tabular}{|c|c|c|c|c|c|c|c|c|c|}
\hline \multirow[t]{2}{*}{ Cluster } & \multicolumn{3}{|c|}{ Tholeiite } & \multicolumn{3}{|c|}{$\overline{\mathrm{AOB}}$} & \multicolumn{3}{|c|}{ EAR } \\
\hline & $\mathbf{N}$ & $\mathbf{M}$ & $\bar{v}$ & $N$ & $\mathbf{M}$ & V & $\mathbf{N}$ & $\mathbf{M}$ & V \\
\hline 1 & 2 & 1.56 & 0.03 & 7 & 1.42 & 0.15 & 4 & 1.35 & 0.03 \\
\hline 2 & 5 & 1.67 & 0.01 & 36 & 1.38 & 0.14 & 18 & 1.30 & 0.18 \\
\hline 3 & 0 & - & - & 16 & 1.17 & 0.05 & 19 & 1.05 & 0.26 \\
\hline 4 & 4 & 1.11 & 0.08 & 11 & 1.29 & 0.02 & 17 & 1.21 & 0.04 \\
\hline 5 & 1 & 1.07 & - & 27 & 1.20 & 0.12 & 22 & 1.19 & 0.05 \\
\hline 6 & 0 & - & - & 11 & 1.20 & 0.06 & 6 & 1.10 & 0.01 \\
\hline 7 & 0 & - & - & 18 & 1.14 & 0.02 & 14 & 1.11 & 0.07 \\
\hline
\end{tabular}

Where $\mathrm{M}$ is mean age (m.y.) $\mathrm{V}$ is variance, and $\mathrm{N}$ is number of samples. Cluster numbers are those given in Figure 5. Clusters 1 and 2 , in the westem SVF, have the oldest mean vent ages for tholeiite, alkalineolivine basalts (AOB), and evolved alkaline rock (EAR) compositions. In general there is a decrease in mean vent age from west to east. However, there are some exceptions. In cluster 3 , for example, eruptions of EAR types have increased over time, giving this cluster a young mean age and a high variance. Age data from Condit et al. [1989]. 
volcanic fields. Without this coincidence, magma will likely form intrusives [Kear, 1964; Settle, 1979; Fedotov, 1981]. Patterns in vent migration in the SVF are somewhat similar to those observed in the San Francisco volcanic field, where known and mapped regional structures exert influences on vent migration patterns, in addition to a general west to east migration in response to plate motions [Tanaka et al., 1986]. Most vents in the SVF, however, are not part of the alignments we have identified. Local structures may play a role in the emplacement of these vents, but regional structures are not a controlling factor. Mapped structures and vent alignments which do occur in the SVF are subtle, and there is no evidence that they are related to major reactivated Precambrian structures, as alignments are in the San Francisco field. The structures and vent alignments that are present in the SVF are therefore more likely to be directly related to Plateau uplift and Basin and Range extensional tectonics, rather than preexisting structures.

The quantitative methods used in this study have enabled us to accurately map subtle vent alignments in the SVF in a reproducible manner. These vent alignments are similar in nature to regional volcanic alignments defined by Kear [1964], in that they are regional in extent (some are over $25 \mathrm{~km}$ long) and vents comprising the alignment are not necessarily aligned, but are nearly aligned. All vent alignments we have identified meet the highest quality ranking (A) used by Zoback and Zoback [1989] to characterize how accurately a particular data point records the tectonic stress field. The WNW-trending zone of high vent density (Figure 3 ), azimuthal directions found through the application of the two-point azimuth method (Table 2), and alignments A, B, C, and F (Figure 5) indicate that vent emplacement has been influenced by $\mathrm{NE}$ extension in the western part of the field. A change in the orientation of $S_{\mathrm{hmin}}$ from dominantly NE in the westem part of the field to NW in the eastem part of the field is indicated by vent alignments $E, I, H$, and $L$. The overall arcuate trend of these alignments mimics the trends of the physiographic and tectonic boundaries of the plateau.

Based on the analysis of local structural features and the patterns of faulting and local folding of basalts, significant structural lineaments in the SVF are oriented NW, ENE, NE, and north (in order of prominence). The NW orientation of regional topographic steps and linear deformation zones, interpreted as complex fault zones, may be related to the WNW trending vent alignments (Figure 5). The orientations of folds and what Crumpler et al. [1989] interpreted as small pull apart basins (e.g., $3 \mathrm{~km} \mathrm{NE}$ of alignment K, Figure 5) along the deformation zones suggest a component of left-lateral strikeslip and that the topographic steps are not a result of simple normal faulting [Crumpler et al., 1989]. These observations are consistent with NE extension in this area, perpendicular to the trend of WNW oriented vent alignments (Figures 3 and 5).

The structural pattern deduced from the analysis of vent distribution and the mapping of faults and flexures is the result of tensional stresses that have been present during the PlioQuatemary. Stress orientations in the SVF have, on average, been radial to the Colorado Plateau during the formation of the field. Models of plateau uplift have demonstrated that tensional stresses in the SVF should be radial to the plateau if the field rests on or near the tectonic boundary of the plateau [Thompson and Zoback, 1979; Brumbaugh, 1987]. Some structures, such as pull apart basins, are consistent with clockwise rotation of crustal blocks in this region [Crumpler et al., 1989] and of the plateau as a whole [Bryan and Gordon, 1986, 1990; Steiner, 1986], also suggesting that the field lies on or near the plateau's tectonic boundary. The stress orientation of N-S trending alignments may be a reflection of a small component of the dominantly E-W tension that is the hallmark of the Basin and Range Province [Zoback, 1989].
Given the tectonic setting in a transitional location at the edge of the plateau, just north of the Basin and Range, all three of these $S_{h \text { min }}$ stress orientations (NE, NW, and E-W) were likely present during eruption of the cinder cones of the SVF.

The limited number of vent alignments ( $D$ and possibly $L$; Table 2; Figure 5) which fall near the $025^{\circ}$ orientation found by Aldrich and Laughlin [1984] to be the characteristic of the Jemez lineament suggests that the SVF, if indeed part of this lineament, is at best on the distal end and was little influenced by the stress fields that controlled the orientation of cinder cones and dikes in other fields along this proposed lineament.

As Brumbaugh [1987] points out, a clear distinction should be made between tectonic and physiographic provinces: a tectonic boundary (or province) should be defined by changes in tectonic elements, some of which include structural style, stress orientations, volcanism, heat flow, seismicity, and changes in crustal thickness. Using these criteria, Brumbaugh [1987, Figure 8] has suggested that the southwestern boundary of the Colorado Plateau extends south from $112^{\circ} \mathrm{W}$ longitude in a concave east arc through the San Francisco and Mormon Mountain volcanic fields, suggesting both fields (and the Westem Grand Canyon field) are tectonically part of the Basin and Range Province. His proposed boundary stops in the area of the Mormon Mountain volcanic field. We suggest that, given the geophysical character (depth to Moho of $\approx 40 \mathrm{~km}$, aseismic) and the minor imprint of a Basin and Range tectonic signature (as shown by these alignment pattems), the SVF has characteristics more common to the Colorado Plateau, and Brumbaugh's proposed tectonic boundary should be extended southeastward, including the SVF on the tectonic boundary of the Colorado Plateau.

\section{CONCLUSIONS}

A total of 404 out of 409 vents mapped in the SVF form seven clusters, using a cluster search radius of $4500 \mathrm{~m}$. These vent clusters have significantly different ages, especially when differentiated by petrologic type. The observed general decrease in cluster age from west to east supports the previously proposed hypothesis that volcanism in the SVF migrates owing to the motion of the North American Plate relative to a fixed mantle source, with activity waxing and waning cluster by cluster in a partially overlapping manner. However, the distribution of clusters and some inconsistencies in the age data suggest that this vent migration pattern is complicated by additional factors, including regional structure as inferred from vent alignments that transect parts of the SVF. Most prominent alignments trend WNW in the western SVF and ENE in the eastern SVF. These different trends intersect in the south central portion of the field, where magmatism was most enduring and cinder cone density is greatest. Other orientations, particularly those observed in local structures and some cinder cone alignments, indicate that local variability in the stress field complicated the patterns of cinder cone emplacement considerably. The vent alignments indicate the presence of fractures or faults, along which magma ascended more readily than elsewhere. The fact that most are subparallel to regional physiographic features, such as the Mogollon Rim, suggests that the overall arcuate pattern observed in cinder cone alignments is a reflection of the structural margin of the Colorado Plateau. This supports the conclusion of Zoback and Zoback [1989] that stress fields near tectonic boundaries reflect structural transitions. The fractures or faults implied by vent alignments within the SVF may be related to extension associated with deformation of the plateau margin, and to a lesser degree to a minor Basin and Range imprint. While the implied structures are regional in extent, they appear to differ significantly from those in other plateaumarginal fields in that they cannot clearly be related to major 
reactivated Precambrian structures, which are lacking around the SVF. Our vent alignment data differ significantly from those seen by other workers in the Zuni-Bandera and Mount Taylor fields, suggesting that if response to a common stress field is a major criterion for inclusion in the proposed Jemez lineament, the SVF is not a part of this feature. Finally, we suggest that the southwestern tectonic boundary of the Colorado Plateau of Brumbaugh [1987] be extended southeastward to include the SVF on its southern boundary.

Acknowledgments. We appreciate the comments of $\mathbf{R}$. E. Stoiber, who reviewed an early draft, and discussions with $D$. U. Wise and M. L. Williams. Careful reviews of the manuscript by Ken Tanaka and Ed Wolfe were extremely helpful. The Southeast Regional Data Center provided computer facilities for this project.

\section{REFERENCES}

Aldrich, M. J., and A. W. Laughlin, A model for the tectonic development of the southeastem Colorado Plateau boundary, $J$. Geophys. Res., 89, 10,207-10,218, 1984.

Aubele, J. C., L. S. Crumpler, and M. Shaffiquillah, K-Ar ages of Late Cenozoic rocks of the central and eastem parts of the Springerville volcanic field, east-central Arizona, Isochron West, 46, 3-5, 1986.

Baker, M. C. W., Volcanoes, spacing, fractures, and the thickness of the lithosphere - A discussion, Earth Planet. Sci. Lett., 23, 161$162,1974$.

Brumbaugh, D. S., A tectonic boundary for the southem Colorado Plateau, Tectonophysics, 136, 125-136, 1987.

Bryan, P., and R. G. Gordon, Rotation of the Colorado Plateau: An analysis of paleomagnetic data, Tectonics, 5, 661-667, 1986.

Bryan, P., and R. G. Gordon, Rotation of the Colorado Plateau: An updated analysis of paleomagnetic poles, Geophys. Res. Lett., 17. 1501-1504, 1990.

Condit, C. D., Field, petrologic and petrochemical data for the westem Springerville-Show Low volcanic field, east-central Arizona (abstract), Eos Trans. AGU, 64, 689, 1984.

Condit, C. D., L. S. Crumpler, J. C. Aubele, and W. E. Elston, Patterns of volcanism along the southem margin of the Colorado Plateau: The Springerville Field, J. Geophys. Res., 94, 7975-7986, 1989.

Condit, C. D., L. S. Crumpler, J. C. Aubele, J. L. Cooper, L. L. Brown, and J. Castro, Thematic geologic maps of the Springerville volcanic field, east-central Arizona, scale 1:100,000, U.S. Geol. Sur. Misc. Invest. Ser. Map, in press, 1992.

Connor, C. B., Cluster analysis and two-dimensional Fourier analysis of cinder cone distribution: Central Mexico and SE Guatemala (abstract), Eos Trans. AGU, 68, 1526, 1987.

Connor, C. B., Cinder cone clustering in the TransMexican Volcanic Belt: Implications for structural and petrologic models, J. Geophys. Res., 95, 19,395-19,405, 1990.

Cooper, J. L., J. L. Aronson, C. D. Condit, and W. K. Han, New K-Ar ages of lavas from the Colorado Plateau-Basin and Range transition zone, east-central Arizona, Isochron West, 55, 28-31, 1990.

Crisp, J. A., Rates of magma emplacement and volcanic output, $J$. Volcanol. Geotherm. Res., 20, 177-221, 1984.

Crumpler, L. S., Alkali basalt through trachyte suite and volcanism, Mesa Chivato, Mount Taylor Volcanic field, New Mexico, part I, Geol. Soc. Am. Bull., 91, 253-255, 1980 a.

Crumpler, L. S., Alkali basalt through trachyte suite and volcanism, Mesa Chivato, Mount Taylor volcanic field, New Mexico, part II, Geol. Soc. Am. Bull., 91, 1293-1313, 1980 b.

Crumpler, L. S., Volcanism in the Mount Taylor region, Field Conf. Guideb. N. M. Geol. Soc., 33, 291-298, 1982.

Crumpler, L. S., The Mount Taylor volcanic field, in Volcanoes of North America, edited by C. A. Wood and J. Kienle, Pp. 300-302, Cambridge University Press, New York, 1990.

Crumpler, L. S., J. C. Aubele, and C. D. Condit, Influence of Quatemary tectonic deformation on volcanism in the Springerville volcanic field, Colorado Plateau, USA (IAVCEI abstract), Bull. $N$. M. Bur. Mines Miner. Resour.,131, 64, 1989.

Delaney, P. T., D. D. Pollard, J. I. Ziony, and E. H. McKee, Field relations between dikes and joints: Emplacement processes and paleostress analysis, J. Geophys. Res., 91, 4920-4938, 1986.

Fedotov, S. A., Magma rates in feeding conduits of different volcanic centers, J. Volcanol. Geotherm. Res., 9. 379-394, 1981.
Hartigan, J. A., Clustering Algorithms, 456 pp., John Wiley, New York, 1975 .

Hasenaka, T., and I. S. E. Carmichael, The cinder cones of the Michoaćn-Guanajuato, central Mexico, their age, volume, distribution, and magma discharge rate, J. Volcanol. Geotherm. Res., 25, 105-204, 1985.

Holm, R. F., and R. A. Cloud, Regional significance of recurrent faulting and intracanyon volcanism at Oak Creek Canyon, southem Colorado Plateau, Arizona, Geology, 18, 1014-1017, 1990.

Holm, R. F., L. D. Nealey, F. M. Conway, and G. E. Ulrich, First-day field trip: Mormon volcanic field, in IAVCEI volume, Field Excursions to Volcanic Terranes in the Westem United States, (IA VCEI vol.), edited by C. Chapin and J. Zidek, Mem. N. M. Bur. Mines Miner. Resour., 46, 41 pp., 1989.

Jackson, E. D., E. A. Silver, and G. B. Dalrymple, Hawaiian-Emperor chain and its relation to Cenozoic circumpacific tectonics, Geol. Soc. Am. Bull., 83, 601-617, 1972.

Kear, D., Volcanic alignments north and west of New Zealand's central volcanic region, N. Z. J. Geol. Geophys., 7, 24-44, 1964.

Keller, G. R., L. W. Braile, and P. Morgan, Crustal structure, geophysical models and contemporary tectonism of the Colorado Plateau, Tectonophysics, 61, 131-147, 1979.

Kelley, V. C. and N. J. Clinton, Fracture systems and tectonic elements of the Colorado Plateau, Univ. N. M. Publ. Geol., 6, 104 pp., 1960.

Le Maitre, R. W., Numerical Petrology, Statistical Interpretation of Geochemical Dala, Dev. in Petrol., vol. 8, 281 pp., Elsevier, New York, 1982.

Lutz, T. M., An analysis of the orientations of large-scale crustal structures: A statistical approach based on areal distributions of poinulike features, J. Geophys. Res., 91, 421-434, 1986.

Merrill, R. K. and T. L. Pewe, Late Cenozoic geology of the White Mountains, Arizona, Spec. Pap. 1, 65 pp., Ariz. Bur. of Geol. and Miner. Technol., Tuson, Ariz., 1976.

Moore, R. B. and E. W. Wolfe, Geologic map of the eastern San Francisco volcanic field, Arizona, scale 1:50,000, U.S. Geol. Surv. Misc. Invest. Ser. Map, MI-953, 1976.

Moore, R. B. and E. W. Wolfe, Geologic map of the east pan of the San Francisco volcanic field, north-central Arizona, scale 1:50,000, U.S. Geol. Surv. Misc. Field Stud. Map, MF-1960, 1987.

Nakamura, K., Volcanoes as possible indicators of tectonic stress orientation-Principles and proposal, J. Volcanol. Geotherm. Res., 2, 1-6, 1977.

Nealey, L. D., Geology and petrology of the Mount Baldy trachytic volcanic complex, White Mountains volcanic field, Apache and Navajo counties, Arizona, Ph.D. dissertation, 320 pp., Univ. of N. M., Albuquerque, N. M., 1989.

Newhall, C. G., G. E. Ulrich, and E. W. Wolfe, Geologic map of the southwest part of the San Francisco volcanic field, north-central Arizona, scale 1:50,000, U.S. Geol. Surv. Misc. Field Stud. Map, $M F \cdot 1958,1987$.

Perry, F. V., W. S. Baldridge, D. J. DePaolo, and M. Shafiqullah, Evolution of a magmatic system during continental extension: the Mount Taylor volcanic field, New Mexico, J. Geol. Geophys., 95, 19,327-19,348, 1990.

Porter, S. C., Distribution, morphology, and size frequency of cinder cones on Mauna Kea volcano, Hawaii, Geol. Soc. Am. Bull., 92, 448-456, 1972.

Sarle, W. S., The cluster procedure, in SAS User's Guide: Statistics (Version 5), 956 pp., SAS Institute Inc., Cary, N. C., 1985.

Settle, M., The structure and emplacement of cinder cone fields, Am.J. Sci., 279, 1089-1107, 1979.

Shoemaker, E. M., R. I. Squires, and M. J. Abrams, Bright Angel and Mesa Butte fault systems in northern Arizona, Cenozoic Tectonics and Regional Geophysics of the Westem Cordillera, edited by R. B. Smith, and G. P. Easton, Mem. Geol. Soc. Am., 152, 341-368, 1978.

Steiner, M. B., Rotation of the Colorado Plateau, Tectonics, 5, 649$660,1986$.

Tanaka, K. L., E. M. Shoemaker, G. E. Ulrich, and E. W. Wolfe, Migration of volcanism in the San Francisco volcanic field, Arizona, Geol. Soc. Am. Bull., 97, 129-141, 1986.

Thompson, G. A., and M. A. Zoback, Regional geophysics of the Colorado Plateau, Tectonophysics, 61, 149-181, 1979.

Ulrich, G. E., and N. G. Bailey, Geologic map of the SP Mountain part of the San Francisco volcanic field, north-central Arizona, scale 1:50,000, US. Geol. Surv. Misc. Field Stud. Map, MF-1956, 1987. 
Ulrich, G. E. and L. D. Nealey, Structural and eruptive pattems in the San Francisco volcanic field, northem Arizona (abstract), Geol. Soc. Am. Abstr. Programs, 8, 641-642, 1976.

Ulrich, G. E., C. D. Condit, K. J. Wenrich, E. W. Wolfe, R. F. Holm, L. D. Nealey, F. M. Conway, J. C. Aubele, and L. S. Crumpler, Excursion 5A: Miocene to Holocene volcanism and tectonism of the southem Colorado Plateau, Arizona, Mem. N. M. Bw. Mines. Miner. Resour., 46, 41 pp., 1989.

Wadge, G., and A. Cross, Quantitative methods for detecting aligned points: An application to volcanic vents in the MichoacínGuanajuato volcanic field, Mexico, Geology, 16, 815-818, 1988.

Warren, D. H., A seismic-refraction survey of crustal structure in central Arizona, Geol. Soc. Am. Bull., 80, 257-282, 1969.

Wemicke, B., and G. J. Axen, On the role of isostasy in the evolution of normal fault systems, Geology, 16, 848-851, 1988.

Wilson E. D., R. T. Moore, and R. T. O'Haire, Geologic map of Navajo and Apache counties, Arizona, scale 1:375000, Ariz. Bur. of Mines, Tucson, Ariz., 1960.

Wilson E. D., R. T. Moore, and J. R. Cooper, Geologic map of Arizona, scale 1:500,000, Ariz. Bur. of Mines and U.S. Geol. Surv., Reston, Va., 1969.

Wolfe, E. W., G. E. Ulrich, and R. B. Moore, San Francisco volcanic field, Arizona, Volcano News, 13, 1-3, 1983.

Wolfe, E. W., G. E. Ulrich, R. F. Holm, R. B. Moore, and C. G. Newhall, Geologic map of the central part of the San Francisco volcanic field, north-central Arizona, scale 1:50,000, U.S. Geol. Surv. Misc. Field Stud. Map, MF-1959, $1987 a$.

Wolfe, E. W., G. E. Ulrich, and C. G. Newhall, Geologic map of the northwest part of the San Francisco volcanic field, north-central Arizona, scale 1:50,000, U.S. Geol. Surv. Misc. Field Stud. Map, $M F$-1957, $1987 b$.

Wong, M. A., A hybrid clustering method for identifying high density clusters, J. Am. Stat. Assoc., 77, 841-847, 1982.
Wong, M. A., and T. Lane, The kth nearest neighbor clustering procedure, J. R. Stat. Soc., Ser. B, 45, 362-368., 1983.

Wong, M. A., and C. Schaak, Using the $k$ th nearest neighbor clustering procedure to determine the number of subpopulations, Am. Stat. Assoc. 1982 Proc. Stat. Compur. Sect., 40-48, 1982.

Zhang, D., and T. Lutz, Structural control of igneous complexes and kimberlites: A new statistical method, Tectonophysics, 159, 137$148,1989$.

Zoback, M. L, State of stress and modem deformation of the northem Basin and Range Province, J. Geophys. Res., 94, 7105-7128, 1989.

Zoback, M. L., and M. D. Zoback, State of stress in the conterminous United States, J. Geophys. Res., 85, 6133-6156, 1980.

Zoback, M. L., and M. D. Zoback, Tectonic stress field of the continental United States, Geophysical Framework of the Continental United States, edited by L. C. Pakiser and W.D. Mooney, Mem. Geol. Soc. Am., 172, 523-539, 1989.

J. C. Aubele and L. S. Crumpler, Department of Geological Sciences, Brown University, Providence, RI 02912.

C. D. Condit Department of Geology and Geography, University of Massachusetts, Amherst, MA 01003.

C. B. Connor, Department of Geology, Florida Intemational University, Miami, F1 33199.
(Received June 18, 1991;

revised April 13, 1992;

accepted April 23, 1992.) 